\title{
Investigation of factor structure, validity and reliability of the criminogenic cognitions scale in Students of Birjand University of Medical Sciences
}

\author{
Jaafar Sadeghi Shahrakht ${ }^{1}(\mathbb{D}),{\text { Qasem } A^{2}}^{2}(D)$ \\ ${ }^{1}$ Department of Psychology, Islamic Azad University, Birjand, Iran. \\ ${ }^{2}$ Corresponding Author; Department of Psychology, Islamic Azad University, Birjand, Iran. \\ Email:ahigh1356@yahoo.com \\ Tel: 09151337399
}

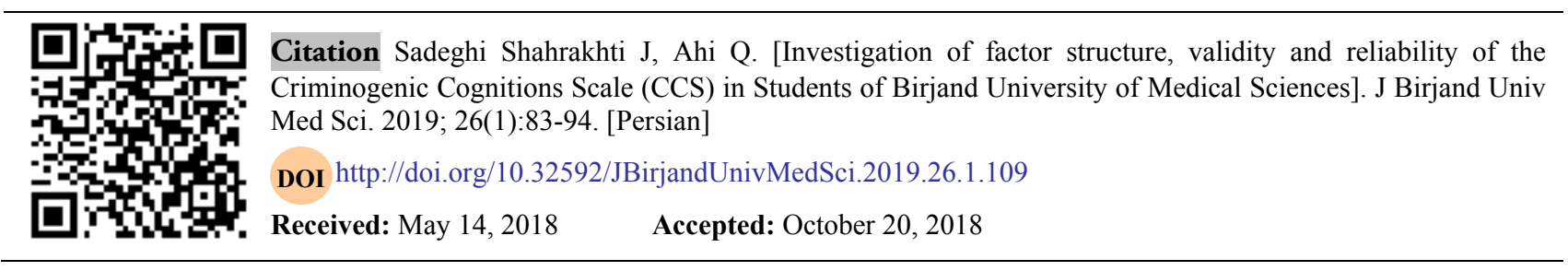

\begin{abstract}
Background and Aim: Behavior misconduct in college students are an important issue. This study aimed to investigate the factor structure, reliability, and validity of the Criminogenic Cognitions scale.

Materials and Methods: This study is a survey of correlation type with exploratory factor analysis, 397 students of Birjand University of Medical Sciences Selected and studied by using cluster sampling method and completed the Criminogenic Cognitions scale, Dark Personality Scale, honesty and empathy subscales and Anger subscale. Data was analyzed using Lisrel (version 8/8) and SPSS softwares (version 22). The reliability coefficient of the questionnaire was calculated through the method of retesting and Cronbach's alpha test and the validity of the questionnaire was determined through exploratory and confirmatory factor analysis.

Results: The result of exploratory factor analysis extracted a 5-factor structure that explained 50.04 percent of the variance of the test. The five factors were named short-term gratification, negative attitude toward authority, failure to accept responsibility, Notions associated with entitlement and Insensitivity to the Impact of Crime, respectively. Cronbach's alpha reliability coefficients for the five factors and the total questionnaire were in the range of 0.65 to 0.89.In addition, correlations between total score of Criminogenic Cognitions scale and scores of psychopathy, Machiavellianism and anger were positive and significant, and correlations between total score of Criminogenic Cognitions scale and scores of honesty and empathy were negative and significant.
\end{abstract}

Fitness indices including Goodness of Fit Index (GFI), Comparative Fit Index (CFI), Incremental Fit Index (IFI) and Root Mean Square Error (RMSEA) equal to $0.88,0.90,0.90$ and 0.073 and showed that the model is fitted with data.

Conclusion: The findings of the study confirmed the obtained five-factor structure of the main questionnaire and provided practical advices for researchers, professionals and organizations responsible for using the scale.

Key Words: Crime; Cognition; Criminogenic Cognitions 


\title{
بررسى ساختار عاملى، روايى و اعتبار يرسشنامه شناختار هاى جرمزا در دانشجويان دانشكاه علوم يزشكى بير جند
}

\author{
جعفر صادقى شاهرخت '(i)، قاسم آهى بان)
}

جكيuه

زمينه و هدف: رفتارهاى جرمزاى دانشجويان يك مسئله مهم است. اين يزوهش با هدف بررسى ساختار عاملى، روايى و اعتبار

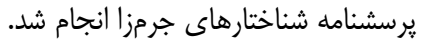

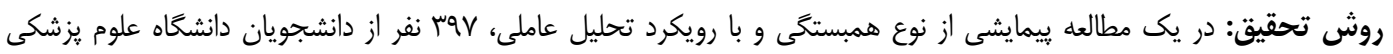

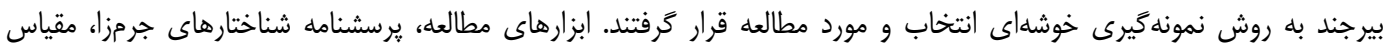

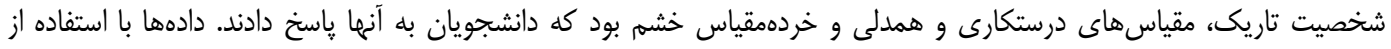

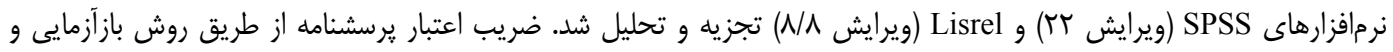

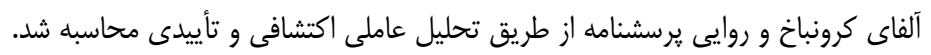

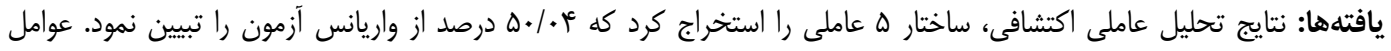

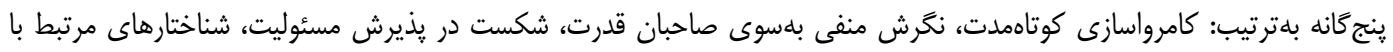

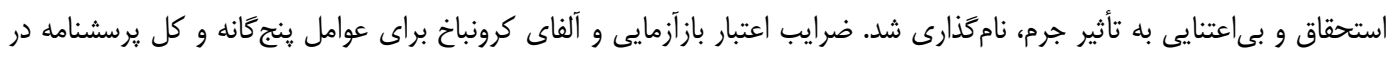

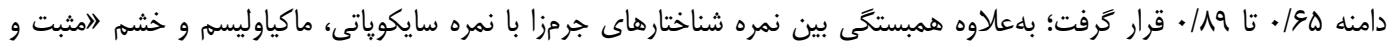

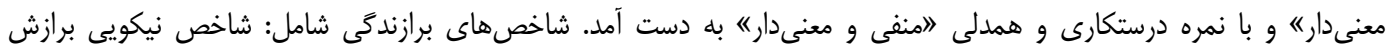

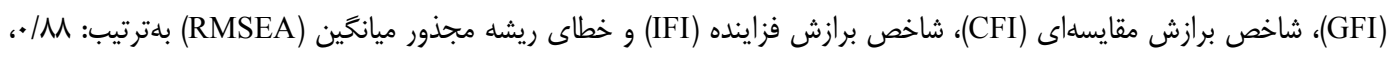

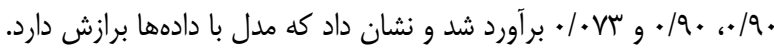

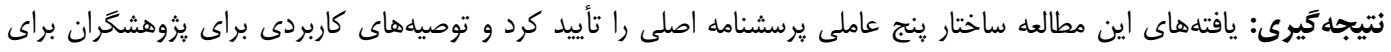
استفاده از اين مقياس ارائه نمود.

وازههاى كليدى: جرم؛ شناخت؛ شناختارهاى جرمزا

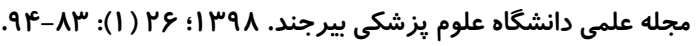
دريافت:

'كروه روانشناسى، واحد بيرجند، دانشگاه آزاد اسلامى، بيرجند، ايران

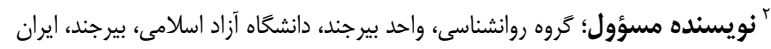

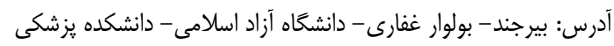
يست الكترونيكى: Ahigh1356@yahoo.com تلفن: و 99 
حفظ رفتار مجرمانه تأكيد دارند و فرض مى كنند كه مجرمان

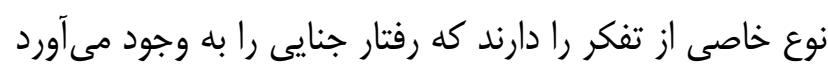

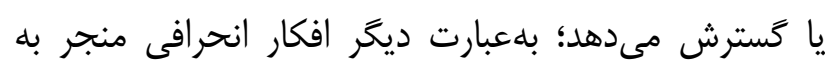

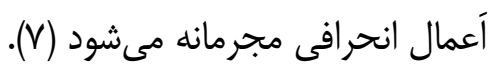

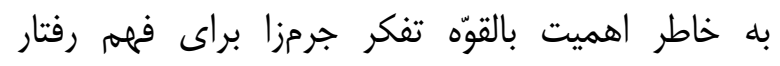

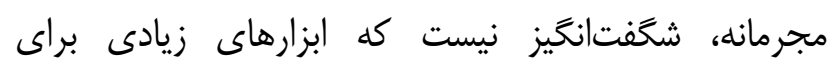

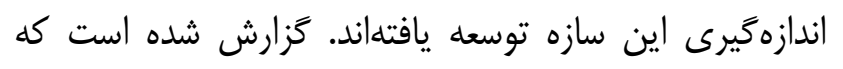

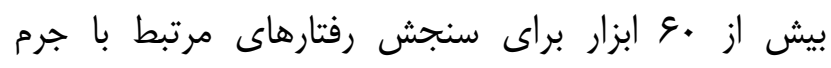

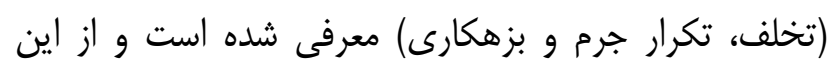

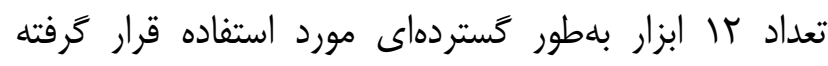

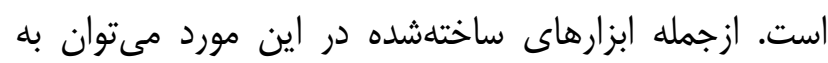

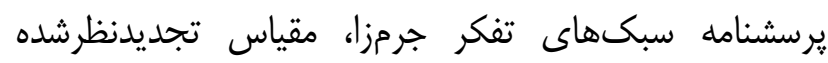

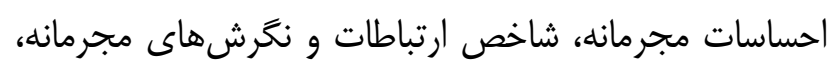

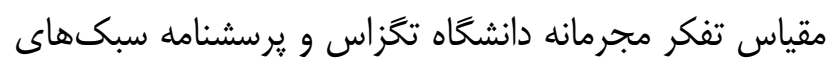

تفكر مجرمانه اشاره كرد (Y).

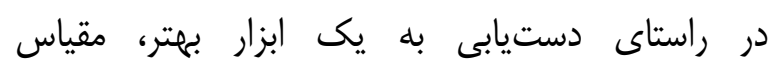

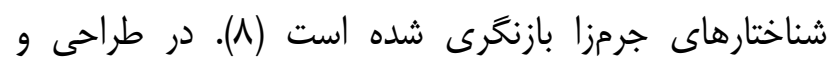

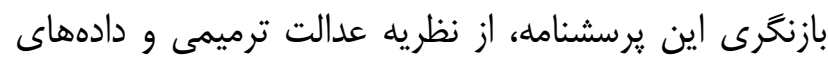

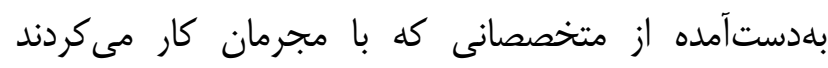

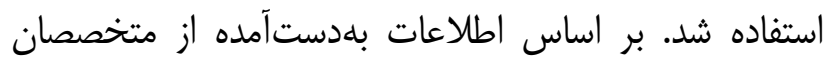

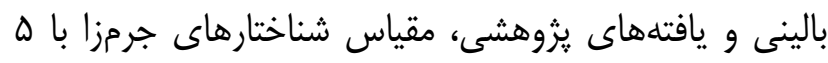

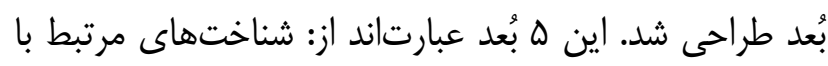

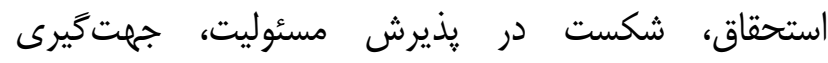
كوتاهمدت، عدم حساسيت (بىاعتنايى) به تأثير جرم و نخَرش

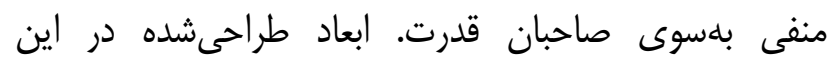

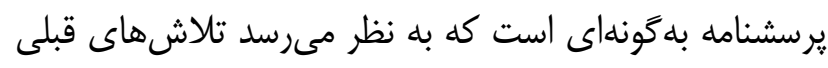

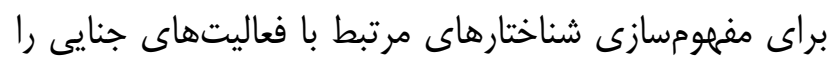

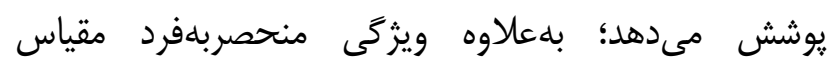

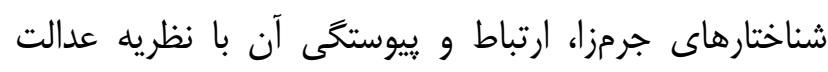

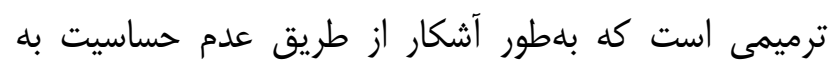

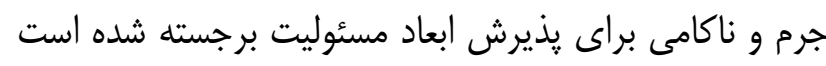

\section{مقله}

رفتارهاى ناساز گارانه و جرمزاى دانشجويان، يك مسئله

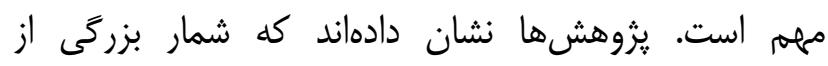

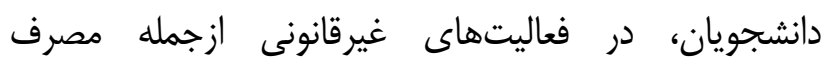

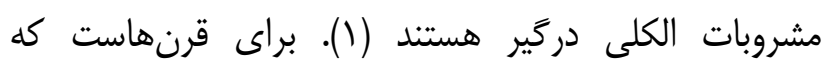
متخصصان درباره فاكتورهايى كه در رفتار جرمزا نقش دارند،

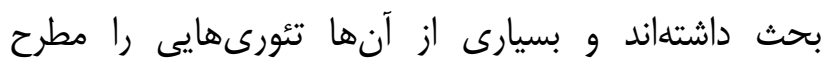

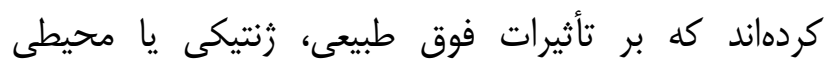
بلهنوان فاكتورهاى برجسته در مجرميت تأكيد داشتهاند (ب)؛

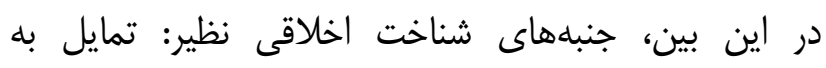

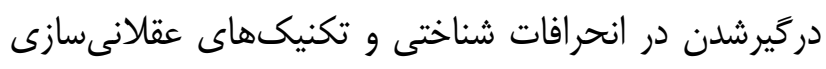

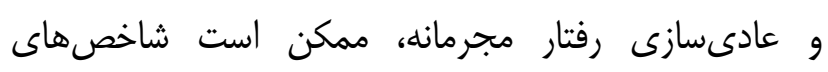
قدرتمند رفتارهاى غير اخلاقى باشند (rّ).

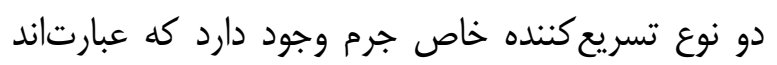

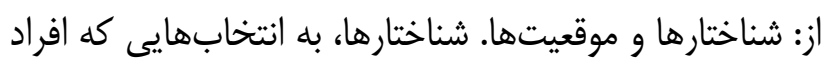

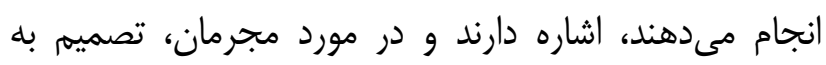

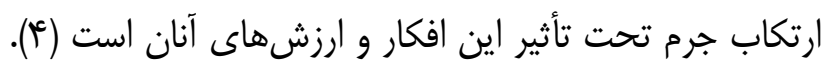

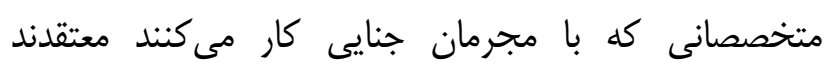
مجرمانى كه در زندگى اصرار بر ارتكاب جرم دارند، مجان مجموعانه

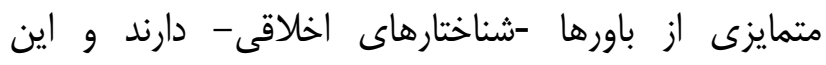

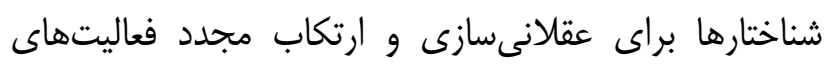

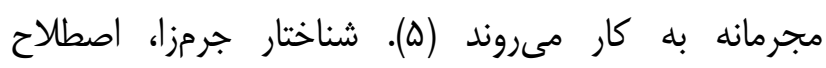

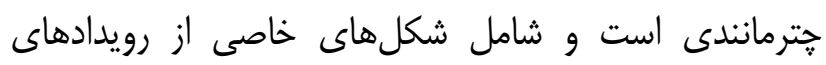

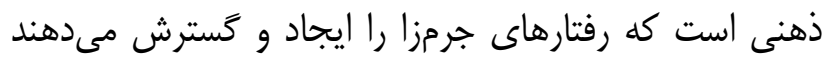

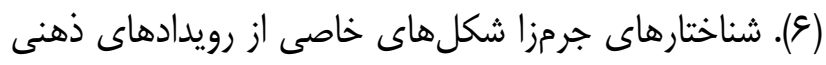

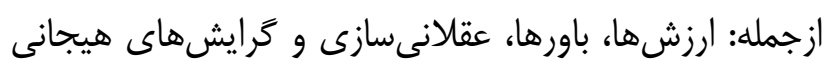

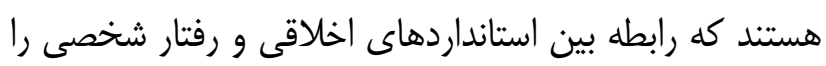
تضعيف مى كنند و در بيشتر تئورىهاى رفتار جنايى ازجمله

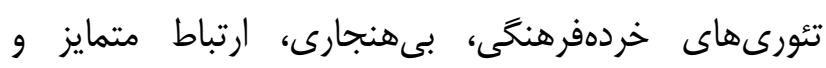

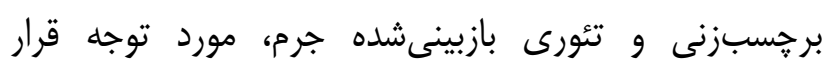

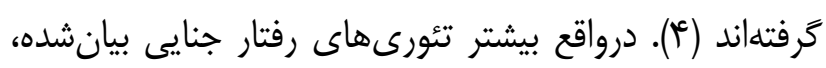

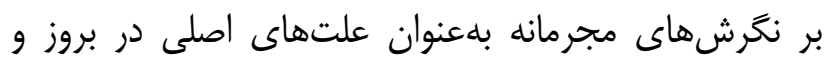




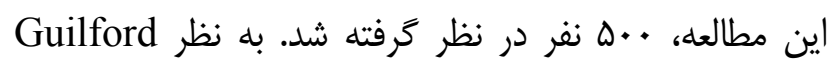

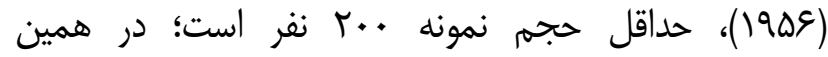

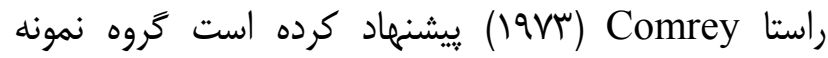

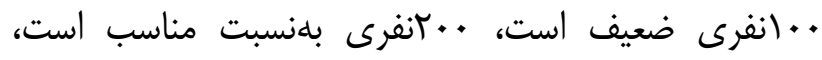

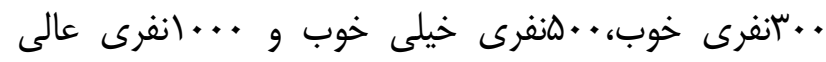

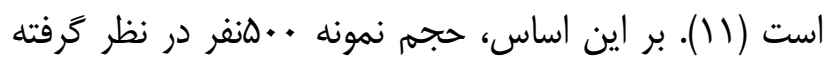
شد. - n

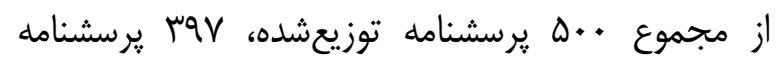
واجد شرايط تحليل تشخيص داده شد. بلمنظور انتخاب نمونه،

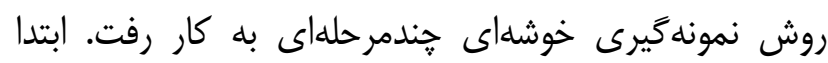

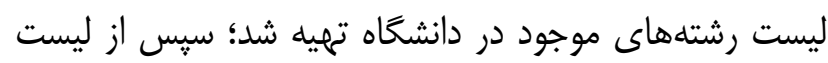

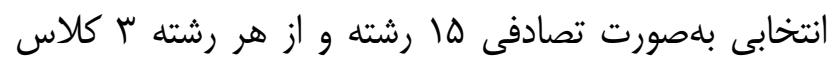

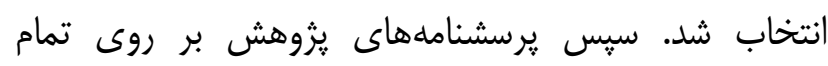

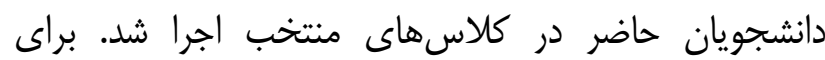

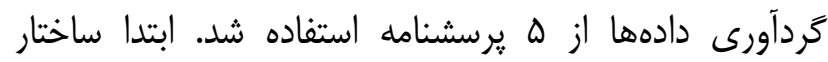

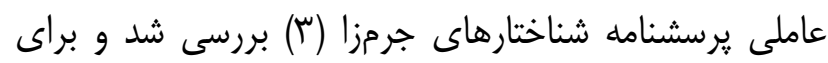
تعيين روايى ملاكى اين يرسشنامه از خردهمقياس سايكوياتى ترانى

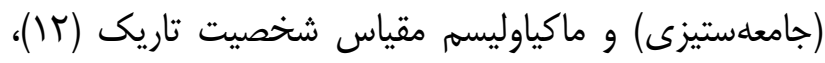

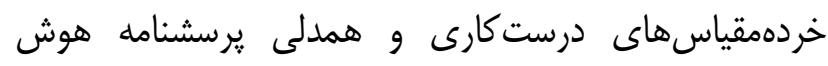

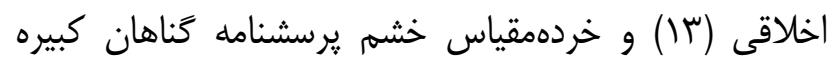

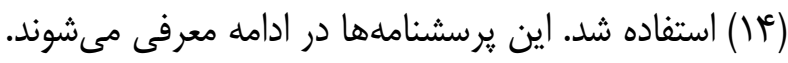

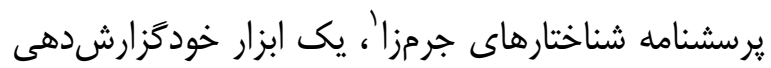

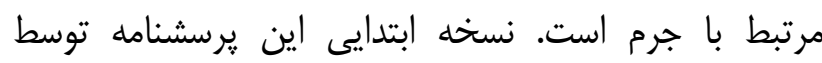
Tangney

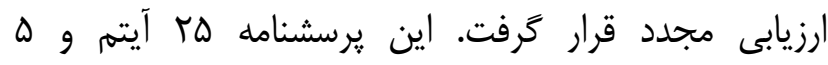

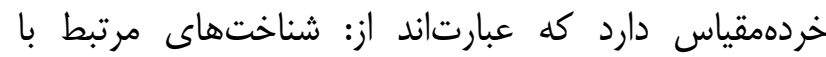

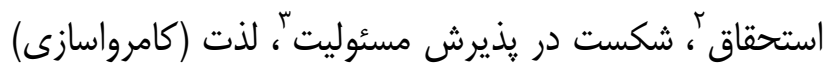

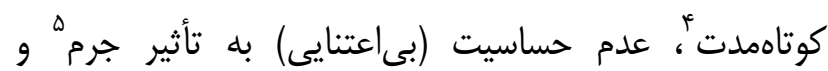

\footnotetext{
${ }^{1}$ Criminogenic Cognitions

2 Notions of Entitlement

${ }^{3}$ Failure to Accept Responsibility

${ }^{4}$ Short-term gratification

${ }^{5}$ Insensitivity to the Impact of Crime
}

اگرجه بيشتر يزوهشهاى انجامشده در دنيا روى جمعيتهاى بزهكار انجام شده است، ولى اين سبك تفكر در جمعيتهاى غيرمجرم نيز قابل مشاهده است و توجه به

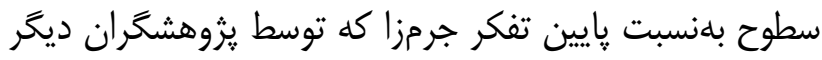

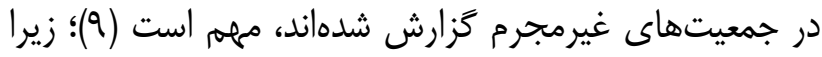

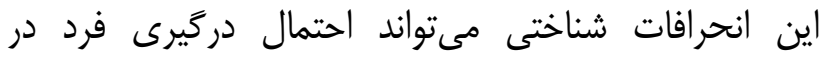

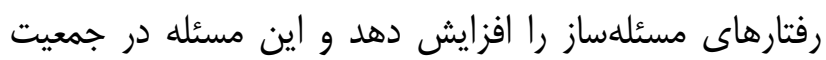

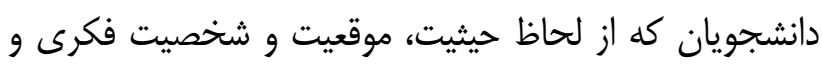

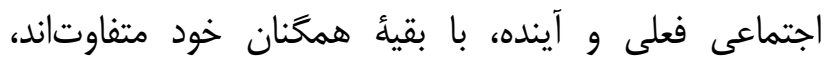

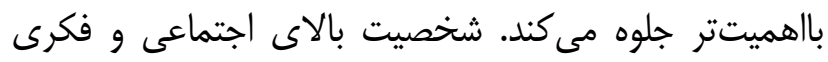

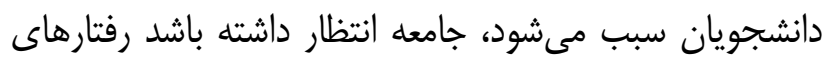

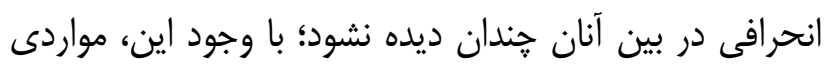

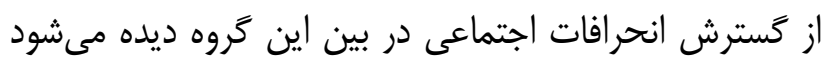

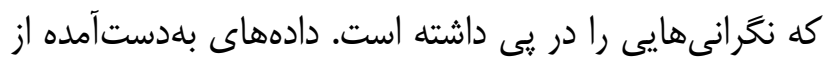
يك مطالعه طولى درباره سلامت نوجوانان كه رفت رفتارهاى دانى دانشجويان تماموقت با غير دانشجويان را مقايسه كرد نشان داد، دانشجويان رفتارهاى مى گسارى بيشترى دارند (· (1).

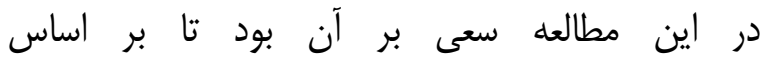

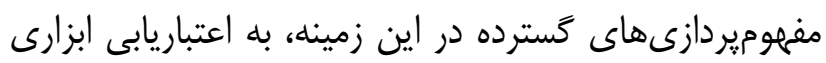
براى سنجش ابعاد شناختارهاى جرمزا يرداخته شود تا زمينه

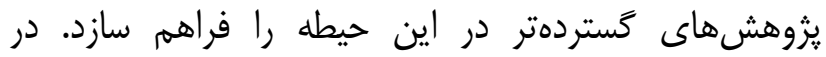

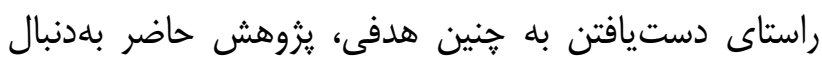

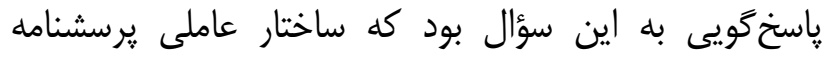

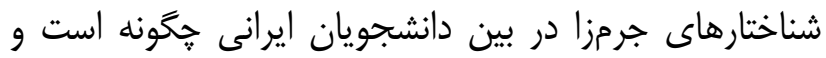
آيا يرسشنامه شناختارهاى جرمزا در بين دانشجويان ايرانى از روايى و اعتبار كافى برخوردار است؟ سنا جناء

يزوهش حاضر، ييمايشى از نوع همبستخى با رويكرد

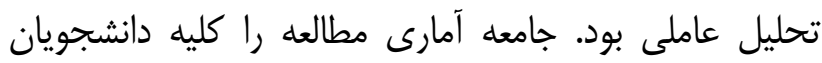

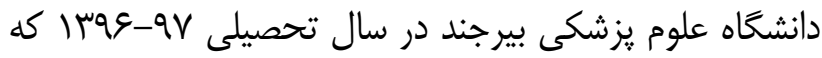

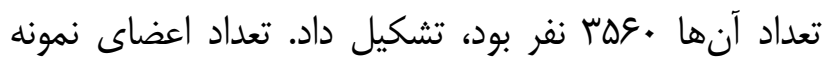


ماكياوليسم، از مقياس شخصيت تاريك' استفاده شد. اين

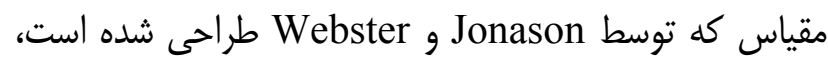
rا گويه دارد كه بر روى يكى مقياس عأدرجهاى نمرهكذارى

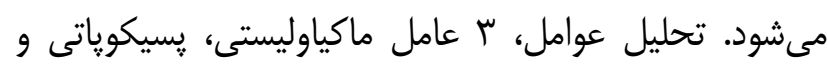

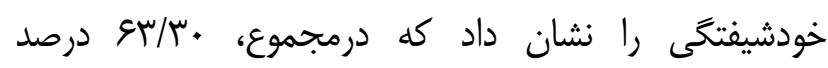

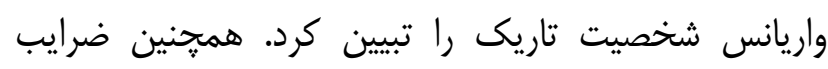

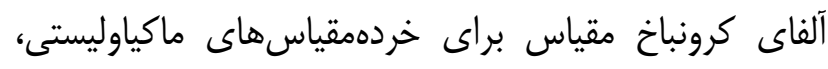

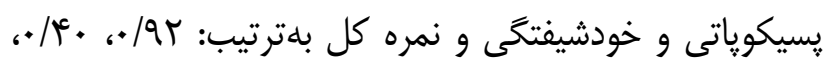

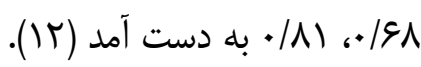

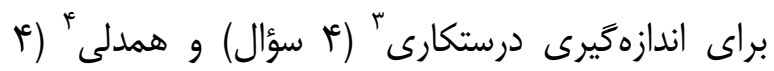
سؤال)، از دو خردهمقياس از يرسشنامه هوش اخلاقى هـ استفاده

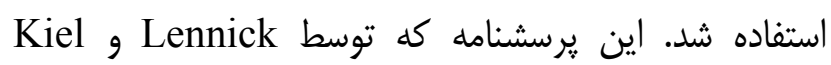

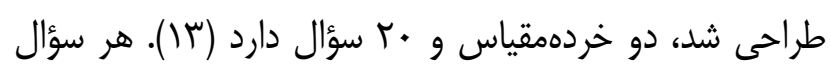

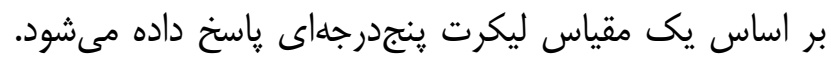

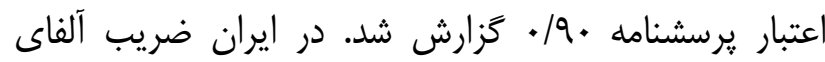

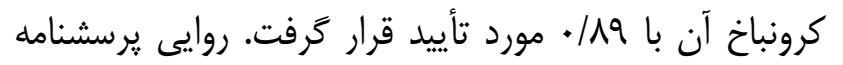

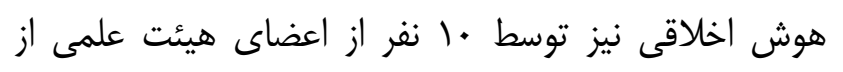

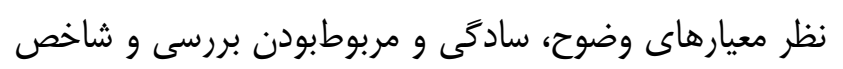

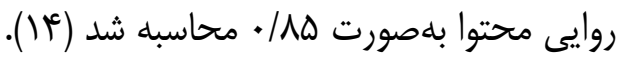

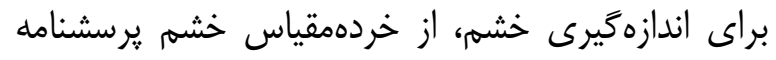

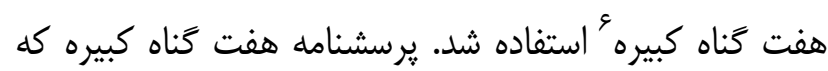

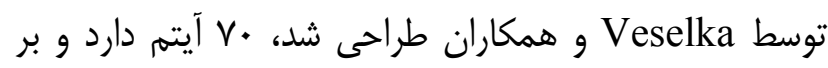
روى يك مقياس هدرجهاى درجلبندى مى شود. ضريب آلفاى

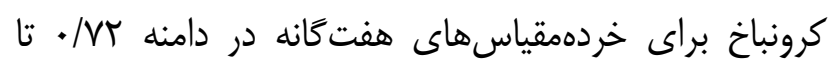
•1/.

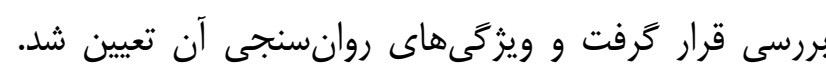
نتايج تحليل عاملى اكتشافى، يك ساختار لواملى استخراج

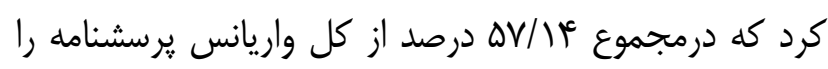
تبيين نمود. اعتبار يرسشنامه از طريق همسانى در دامنه

${ }^{2}$ Dark Personality Scale

${ }^{3}$ Honesty

${ }^{4}$ Empathy

${ }^{5}$ Moral intelligence inventory

${ }^{6}$ Deadly sins
نخرش منفى بلهسوى صاحبان قدرت'. در اين يرسشنامه،

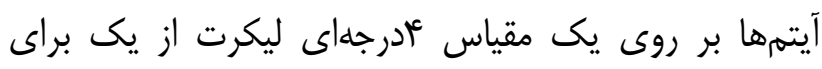

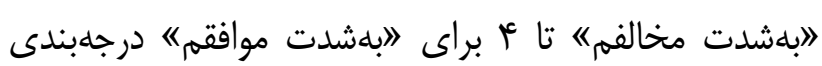

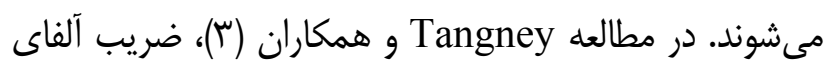

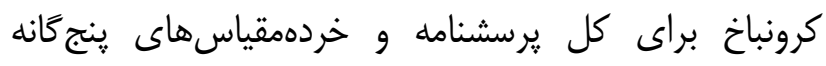

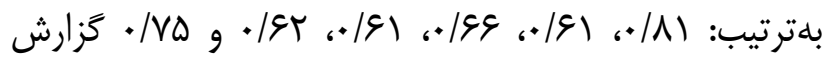

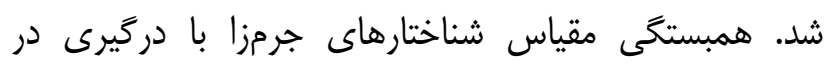

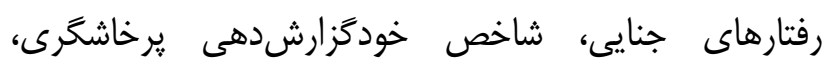
تكانشيذيرى و فقدان همدلى، نشاندهنده روائي روايى ابزار بود.

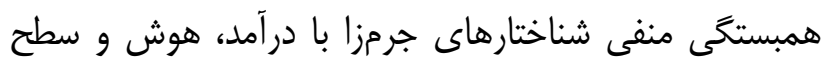

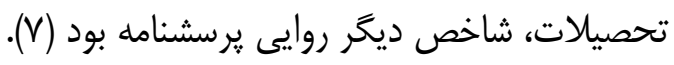

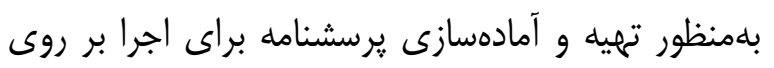

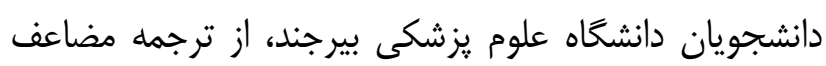

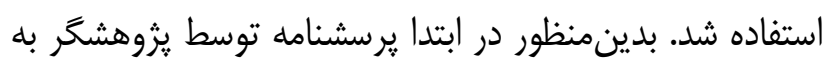
فارسى ترجمه شد و سيس نسخه ترجمهشده و نسخه اصلى

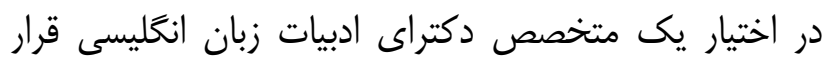

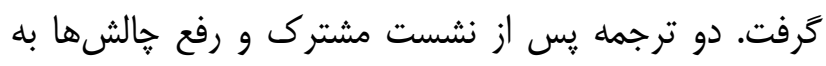

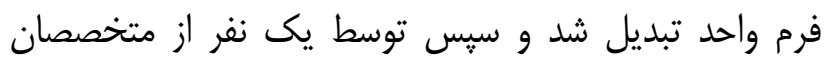

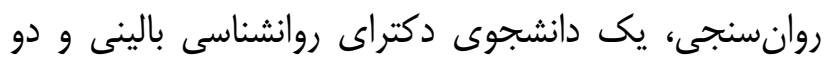

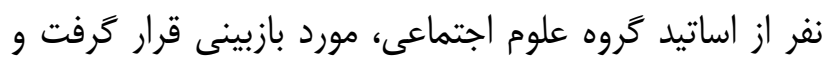

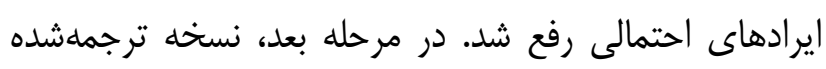
توسط همان متخصص دكتراى ادبيات زبان انخليسى بلهطور

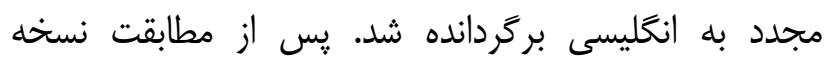

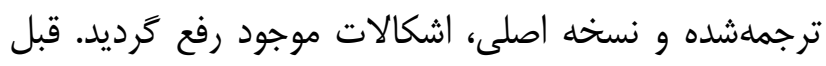

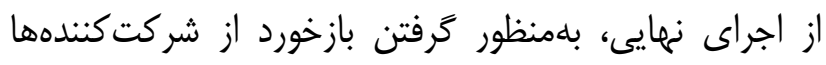

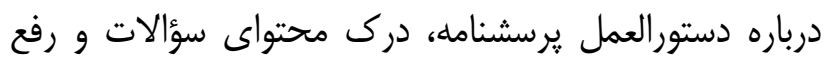

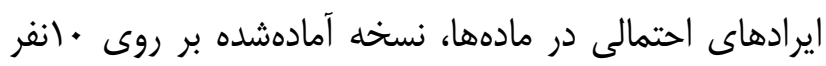

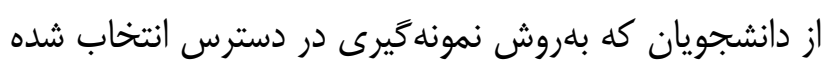

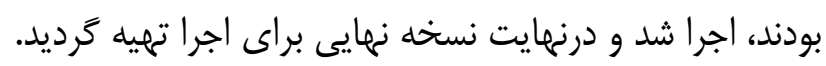

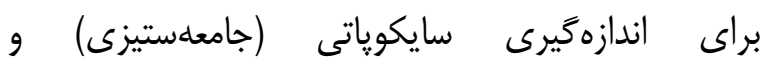

\footnotetext{
${ }^{1}$ Negative Attitudes toward Authority
} 
تحليل عاملى، آزمون كرويت بارتلت' و آزمون KOM' انجام

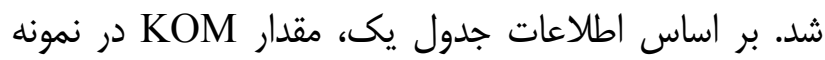

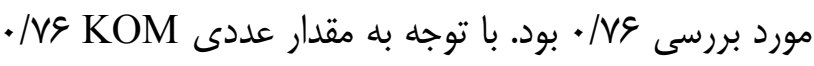

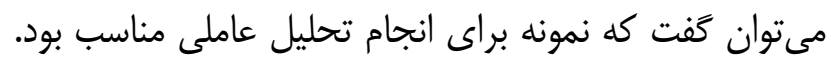

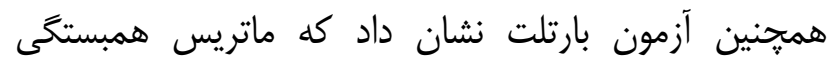

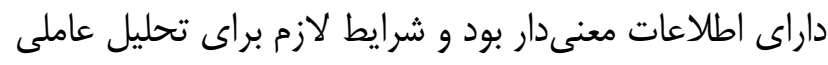

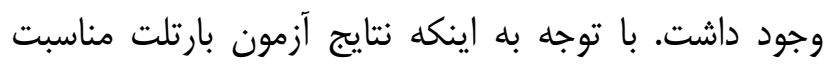

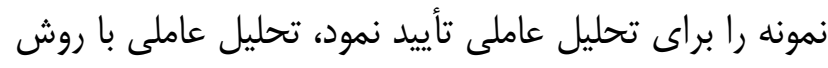

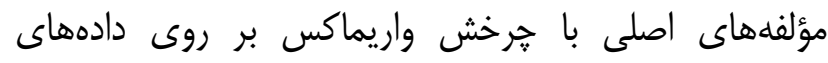

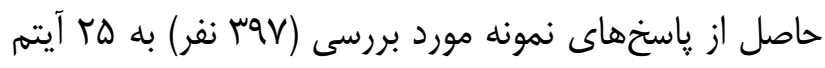

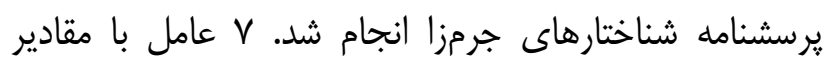

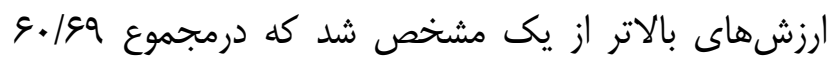

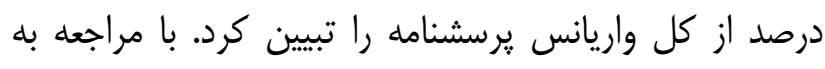

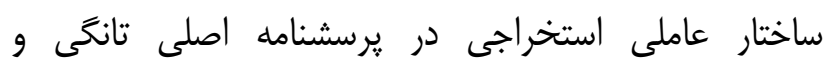

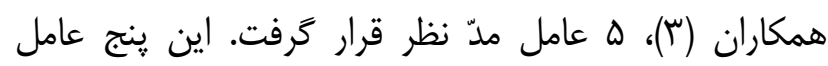

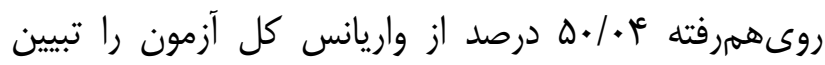
نمود (جدول ()).

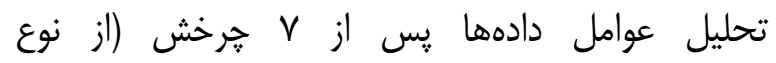
واريماكس) به بهترين ساختار عاملى رسيد (جدول بل ب). طبق نتايج جدول: - عامل اول (كامرواسازى كوتامددت) با ارزش عاملى

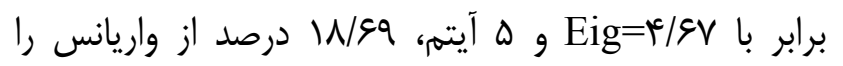

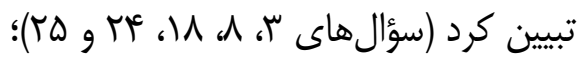

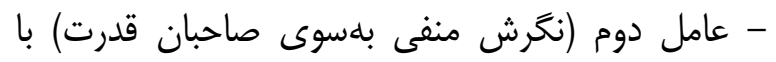

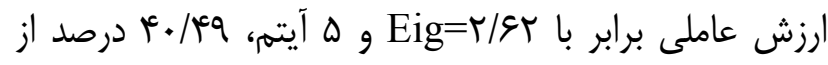

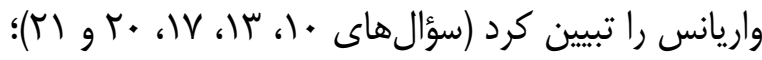

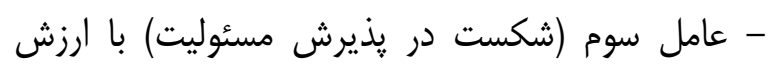

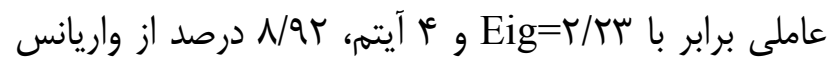
را تبيين كرد (سؤال هاى r، ه، 9 و זr)؛ - عامل جهارم (شناختهاى مرتبط با استحقاق) با ارزش

\footnotetext{
${ }^{1}$ Bartlett test

${ }^{2}$ Kaiser-Mayer-Olkin
}

تا • • • قرار كرفت كه نشاندهنده همسانى درونى بالاى يرسشنامه هفت كناه كبيره بود (IV).

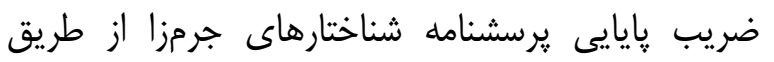

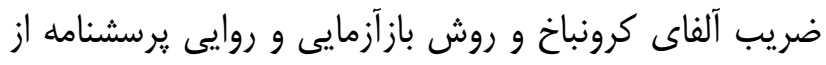
طريق تحليل عاملى اكتشافى (روايى سازه و همسانى درونى)،

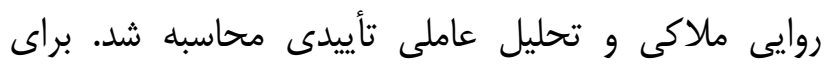

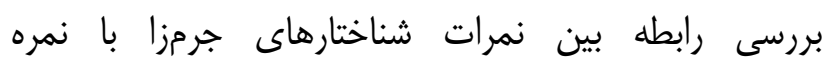

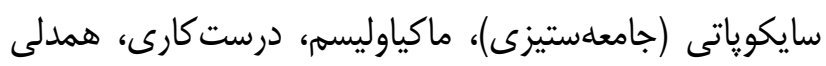

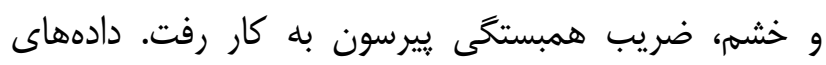

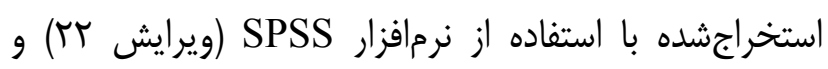
Lisrel برگرفته از ياياننامه دانشجويى با كد اخلاق مصوب تحزئ كميته

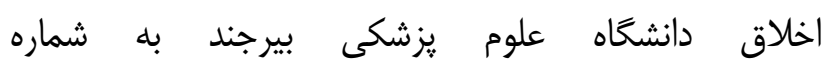
ir.bums.rec.1397.32

يافته ها از مجموع .0 يرسشنامه توزيعشده، يرسشنامههايى كه

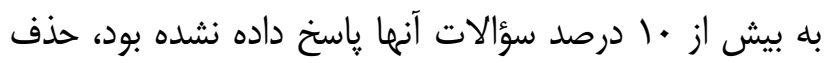

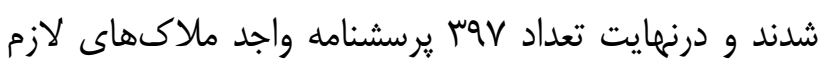

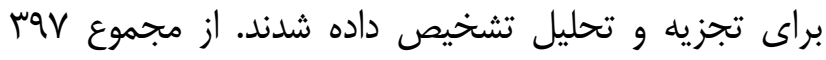

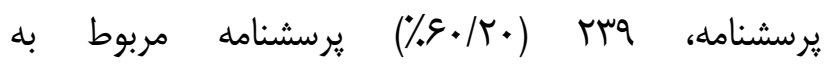

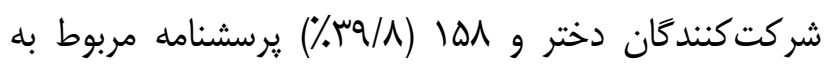

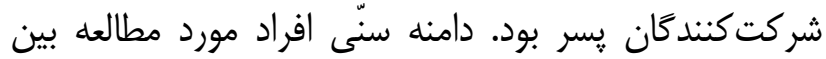

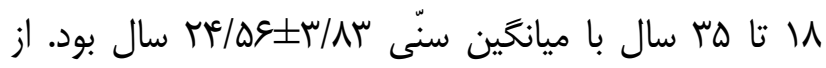

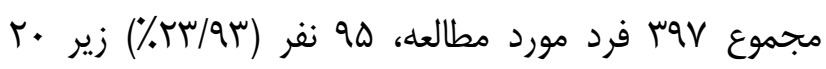

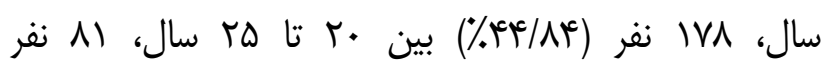

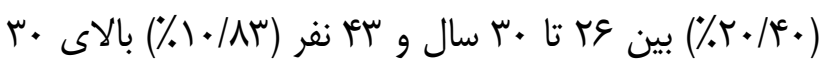
سال سن داشتند. براى بررسى ساختار عاملى يرسشنامه، پاسخهاى افراد

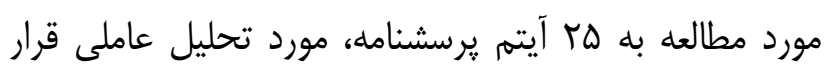
كرفت. ابتدا براى بررسى مناسبت و كفايت نمونه براى انجام 


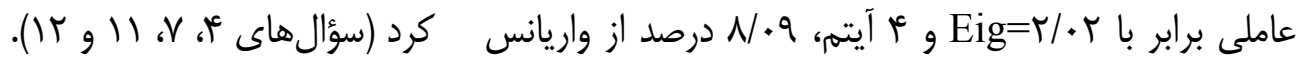

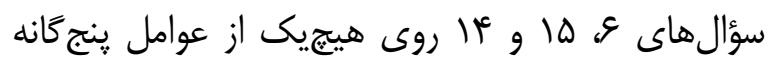

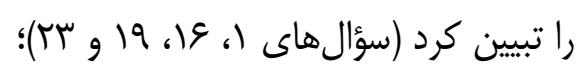

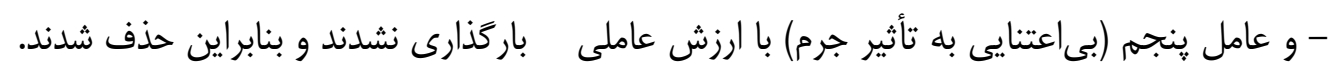

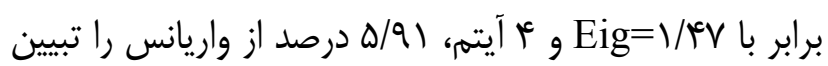

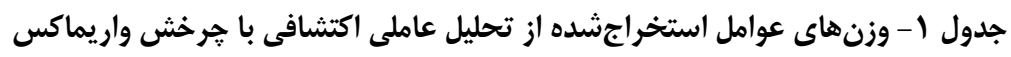

\begin{tabular}{|c|c|c|c|c|c|c|}
\hline \multirow[b]{2}{*}{ 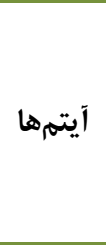 } & \multirow[b]{2}{*}{ 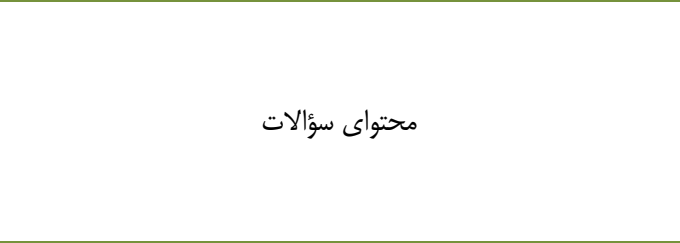 } & \multicolumn{5}{|c|}{ مؤلفهها } \\
\hline & & $\begin{array}{c}\text { (كامرواسازى) } \\
\text { كوتاهمدت }\end{array}$ & 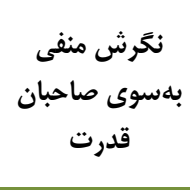 & شذئيرش & شناختهاى & جساسيت \\
\hline 1 & وقتى جيزى را مىخواهم، انتظار دارم مردم آن را به من بدهند. & - & - & - & . & - \\
\hline \& & تخا زمانى كه همهى آنجهه شايستخىاش را دارم دريافت نكنم، راضى & - & - & - & - & - \\
\hline 19 & از مردم انتظار دارم با من بهتر از ديخران رفتار كنند. & - & - & - & $\cdot / V E V$ & - \\
\hline 19 & من اصرار دارم احترامى كه شايستهى آن هستم را دريافت نمايم. & - & - & - & 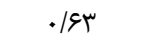 & - \\
\hline r & شايستخى و حق من بيش از ديخران است. & - & - & - & $\cdot / \Lambda \cdot r$ & - \\
\hline r & تجربيات بد دوران كودكى، تا حدودى مسبب شرايط فعلى من است. & - & - &. & - & - \\
\hline$\Delta$ & قدرتمند تعيين مى شنم آنجه در زندگى من اتفاق مىافتد عمدتاً توسط افراد & - & - & . $/ 9 \mathrm{rr}$ & - & - \\
\hline 9 & است خاطر سابقهام، به جيزهاى زيادى متهم مىشوم كه كار من نبوده & - & - & r & - & - \\
\hline 10 & 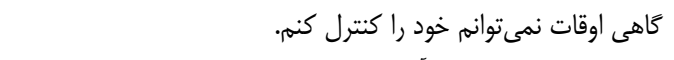 & - & - & - & - & - \\
\hline tr & من از اول، مجرم به دنيا آمدهام و 》مجرم مادرزاد" هسته. & - & - & .1999 & - & - \\
\hline r & آينده غيرقابلييشيينى بوده و برناملريزى براى آن بىفايده است. & $\cdot|\wedge| \mid$ & - & - & - & - \\
\hline$\wedge$ & با وجودى كه دستخير شدم اما به ريسكش مىارزيد. & $\cdot / V \Delta 9$ & - & - & - & - \\
\hline 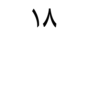 & براى دانداز و سرمايهنذارى جيزى كنيد. الآن هم مىتوانى آن را داشته باشى، بايد & $\cdot / V^{4}$. & - & - & - & - \\
\hline re & به نظر من لذتبردن از امروز، بهتر از نحَرانى در مورد فردا است. & . & - & - & - & - \\
\hline ra & دوست ندارم ملزم به انجام يك برنامهى كارى منظهم باشم. & . IGTE & - & - & - & . IGYG \\
\hline r & جرم يا جرائم من واقعاً به كسى صدمه نزده است. & - & - & - & - &.$/ 098$ \\
\hline$\checkmark$ & سرقت درصورتى كه قربانى دهار جراحت جسمى نشود اشكالى ندارد. & - & - & - & - & / /arq \\
\hline 11 & قربانيان جرم معمولاً با كذر زمان با آن كنار مىآيند. & - & - & - & - & - MET \\
\hline it & 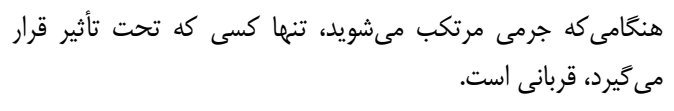 & - & - & - & - & .1948 \\
\hline If & جامعه، در مورد جرم من بيش ازحد بزر گنمايى و اغراق مى كند. & - & - & - & - & - \\
\hline 1. & 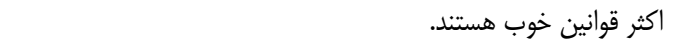 & - &.$/$ V9G & - & - & - \\
\hline וr & بيشتر افسران و نيروهاى يِليس از قدرت خود سوء استفاده مى كنند. & - & $\cdot /$ VAT & - & - & - \\
\hline iv & مسئولين و افراد صاحب قدرت معمولاً حواسشان به منافع من هست. & - & $\cdot / V^{M} F$ & - & - & - \\
\hline$r$. & خوبى يشت يَ آن است. به من مى گويد كارى را انجام دهم، معمولاً دليل & - & $\cdot / \mathrm{r} \cdot$ & - & - & - \\
\hline r) & مقامات و افراد داراى قدرت، معمولاً از ديخران سوء استفاده مى كنند. & - & . MTT & - & - & - \\
\hline
\end{tabular}


جدول r- ضريب آلفاي كرونباخ و ضريب اعتبار به شيوه بازآزمايى

\begin{tabular}{|c|c|c|c|}
\hline \multicolumn{2}{|c|}{ 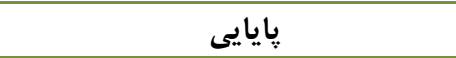 } & \multirow{2}{*}{ تعداد آيته } & \multirow{2}{*}{ 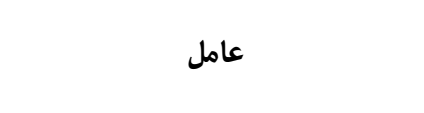 } \\
\hline 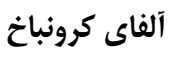 & 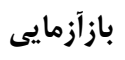 & & \\
\hline$\cdot / \Lambda \&$ & $\cdot|\wedge|$ & $\Delta$ & لذت (كامرواسازى) كوتاهمدت \\
\hline$\cdot / 19$ & $\cdot / V q$ & $\Delta$ & نخَرش منفى بلهوى صاحبان قدرت \\
\hline$\cdot / \Lambda$. & $\cdot / V 9$ & c & شكست در קذيرش مسئوليت \\
\hline .199 & $\cdot 190$ & c & شناختهاى مرتبط با استحقاق \\
\hline$\cdot / V Q$ & .199 & c & عدم حساسيت (بىاعتنايى) به تأثير جرم \\
\hline$\cdot /\left.\Lambda\right|^{2}$ & $\cdot / V^{\mu}$ & tr & نمره كلى شناختارهاى جرمزا \\
\hline
\end{tabular}

جدول بـ- ماتر يس همبستكى بين نمره شناختارهاى جرمزا و سايكوياتى (جامعه ستيزى)، ماكياوليسم، درستكارى، همدلى و خشم

\begin{tabular}{|c|c|c|c|c|c|}
\hline 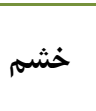 & 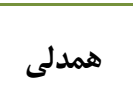 & درستكارى & ماكياوليسم & (جامعهستيزى) & 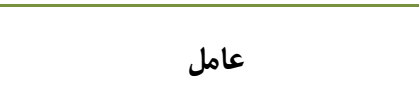 \\
\hline$\cdot / \Lambda^{* * * *}$ &.$- / 19^{* * *}$ & $-\cdot / r \cdot * *$ & . & $\cdot / 4 \cdot *$ & لذت (كامرواسازى) كوتاهمدت \\
\hline$\cdot|<|^{* * *}$ &.$- / 19^{* * *}$ & $-\cdot / \mu^{* * *: *}$ & $\cdot / / V^{* *}$ & $\cdot / \pi \mu^{* * *}$ & نكَرش منفى بلهوى صاحبان قدرت \\
\hline$\cdot / \kappa^{* * * *}$ & $-\cdot / \Gamma \varphi^{* * *}$ & $-\cdot / \Gamma r^{* * * *}$ & $\cdot / \gamma^{* * *}$ &.$/ 4^{* * 3}$ & شكست در پذيرش مسئوليت \\
\hline$\cdot / \cdot \cdot^{* * *}$ & $-\cdot / r^{*}$ & $-\cdot / 1 \kappa^{* * *}$ & $\cdot 118^{* * *}$ & $\cdot / r \cdot * *$ & شناختهاى مرتبط با استحقاق \\
\hline$\cdot / 19^{* * * *}$ & $-\cdot / T \gamma^{* * *}$ & $-\cdot / \mu \varphi^{m * * *}$ & $\cdot / \mu^{* * *}$ & $\cdot / 1)^{x+m}$ & عدم حساسيت (بىاعتنايى) به تأثير جرم \\
\hline$\cdot|\Delta|^{* *: *}$ & - & $-\cdot / q^{* * *}$ & $\cdot / \gamma^{* *}$ & 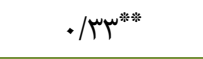 & نمره كلى شناختارهاى جرمزا \\
\hline
\end{tabular}

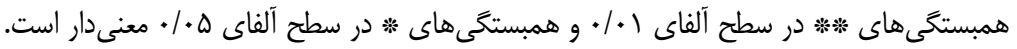

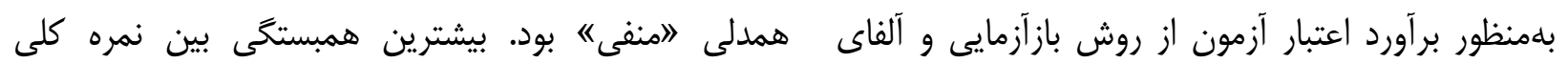

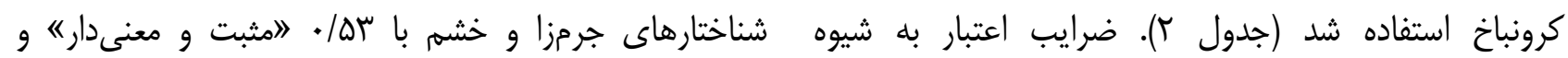

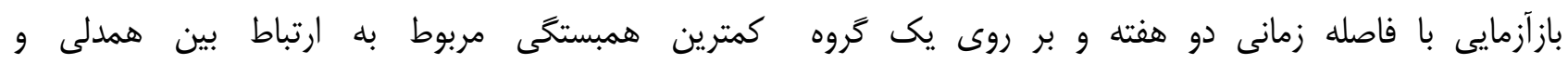

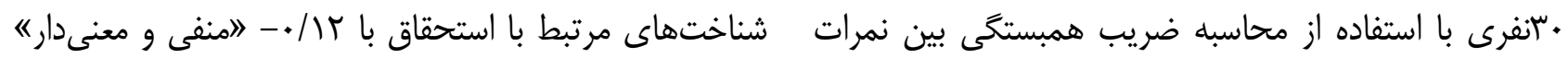

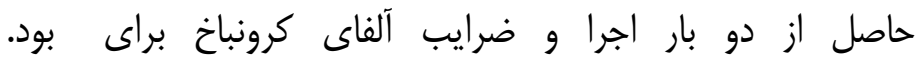

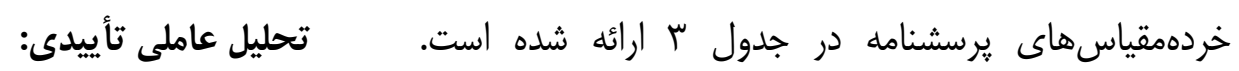

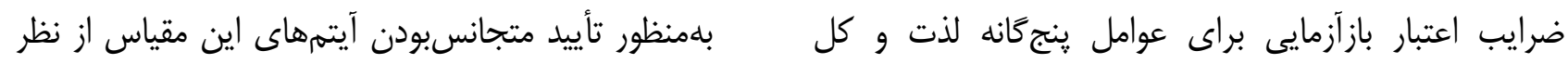

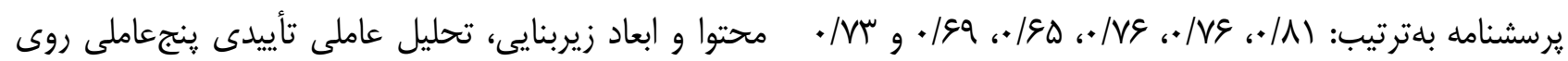

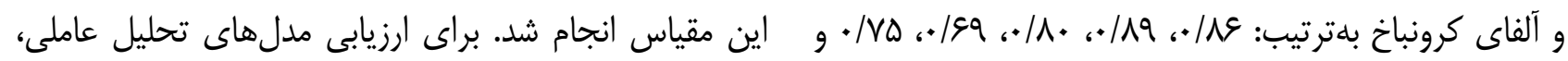

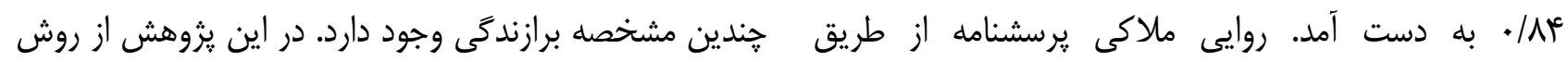

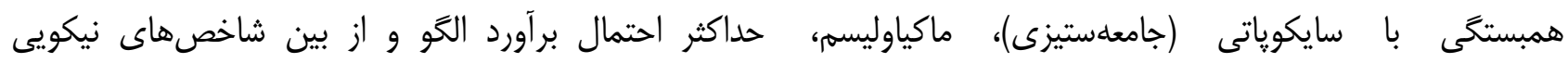

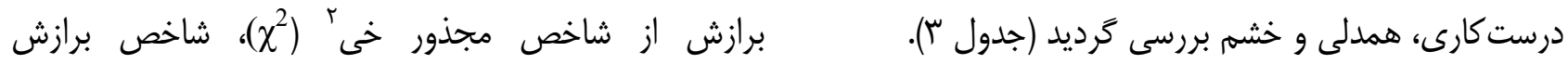

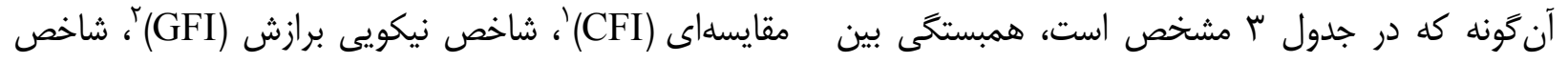

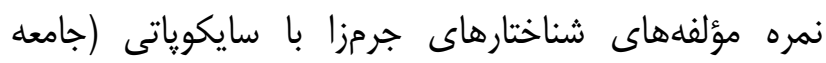


جدول f - شاخصهاي برازش الكَوى تحليل عاملى تأيدى يرسشناهه سبكهاي تفكر

\begin{tabular}{|c|c|c|c|c|c|}
\hline RMSEA & IFI & CFI & GFI & مجذور خى T & شاخص \\
\hline$\cdot / \cdot n$ &.$/ 9$. & $+/ 9+$ & $\cdot / M$ & SIVAT & برازش \\
\hline
\end{tabular}

اندازمخيرىشده توسط اين يرسشنامه، با دامنهاى از سازههاى

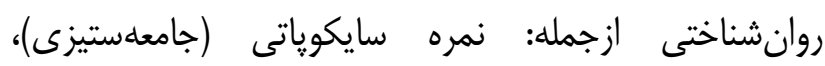

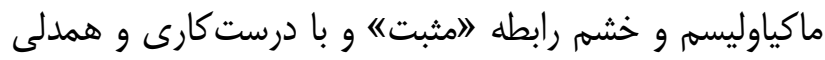

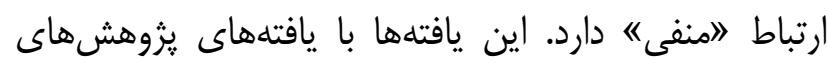

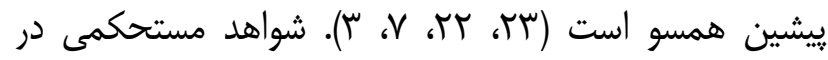

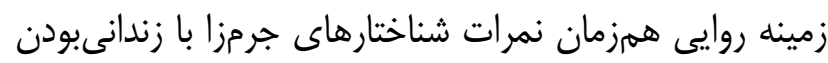

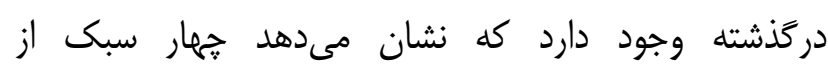

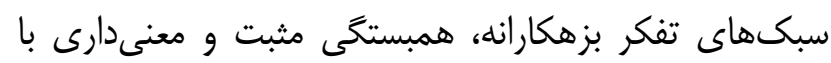

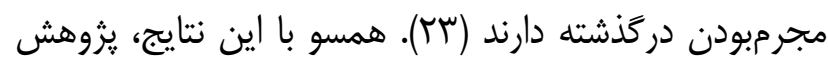

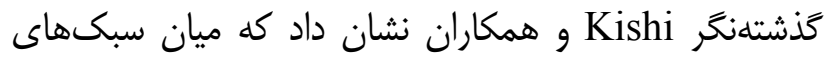
تفكر بزهكارانه و ارتكاب به جرم دركذشته، همبستكى مثنبتى

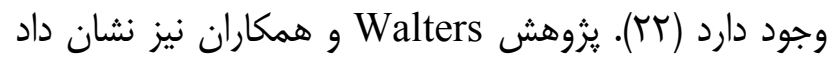
كه تفكر بزهكارانه واكنشى، نقش ميانجى را درد درد رابطه ميان

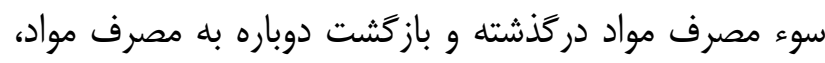

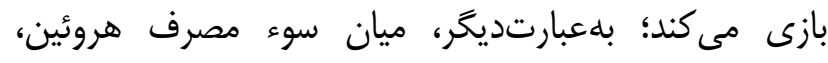

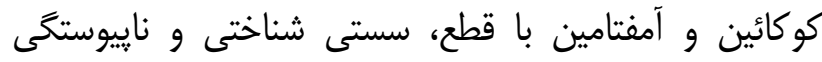

$$
\text { همبستخى معنى دارى وجود دارد (ז' (T). }
$$

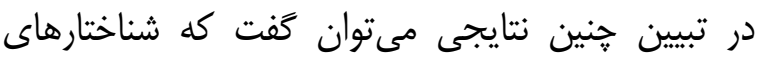

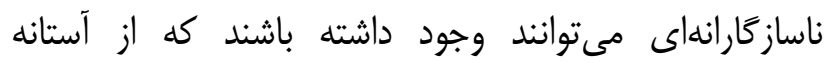
بيمارى روانى عبور نكنند، اما بر مجرميت تأثير تذار باشنداندان. بسيارى از نظريههاى برجسته جرمشناسى مانند: نظريههاى

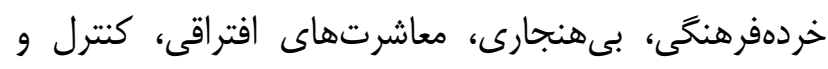

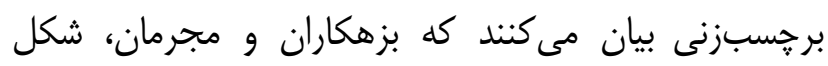

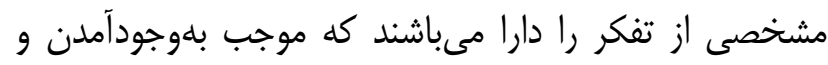
ترويج رفتارهاى بزهكارانه و جنايى در آنها مى تشود (V)

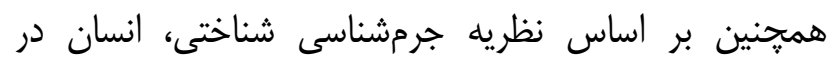

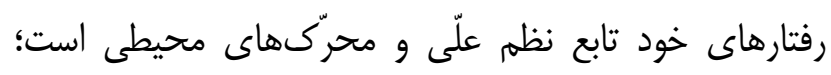

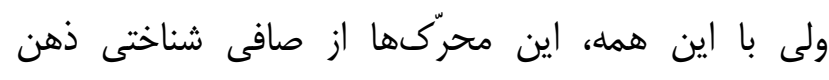

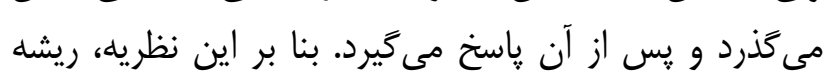

برازش نرمالشده (NFI)'، خطاى ريشه مجذور ميانخين (RMSEA)

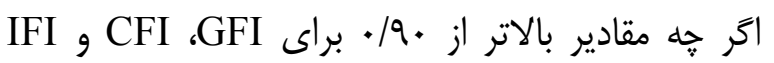
نشاندهنده برازش خوب الخو با دادههاست، اما مقادير بالاتر

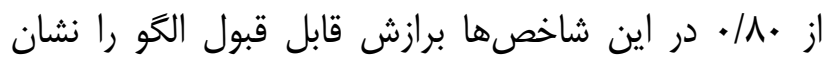

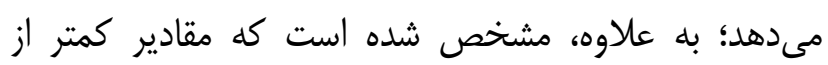

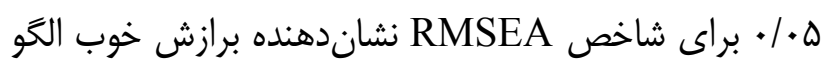

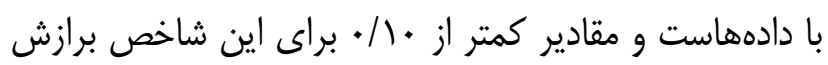

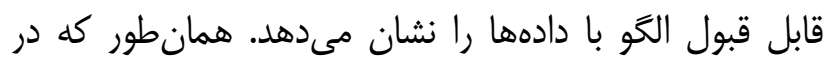

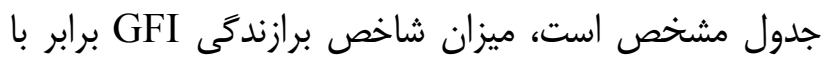

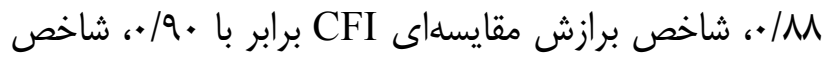

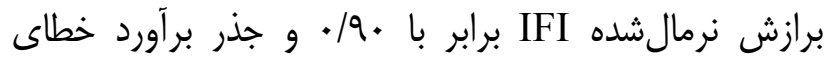

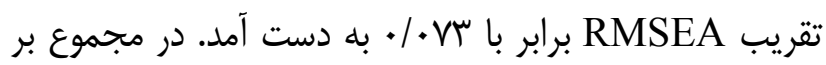

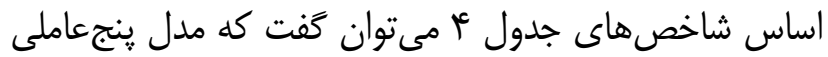

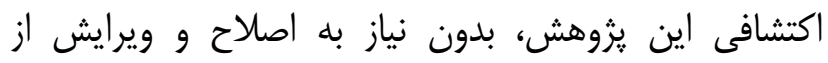
برازش مناسب برخوردار است.

يافتههاى بلهدستآمده از اين مطالعه، از ساختار عاملى بdدستآمده در مطالعه اصلى (ऍّ) حمايت كرد. اين يافتهها هماهنَ با يافتهاى يزوهشخَان ييشين نشان مىدهد كه

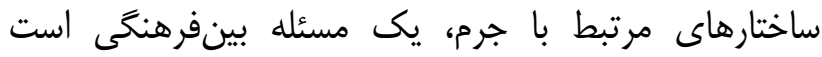

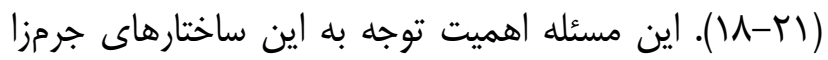

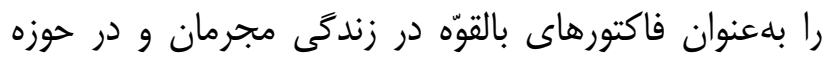

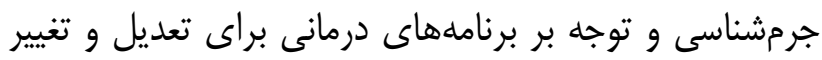
اين شناختارها را برجسته مىسازد (·r).

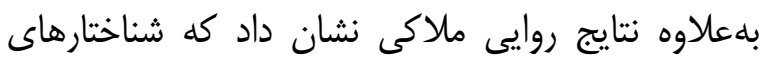

\footnotetext{
1 Normed Fit Index

${ }^{2}$ Root Mean Square Error
} 
يعنى شخصيت، نقش تعيين كنندهاى در ايجاد جرم و جنايت

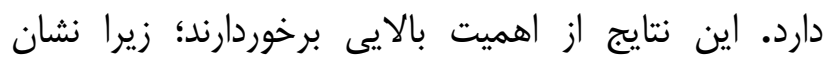

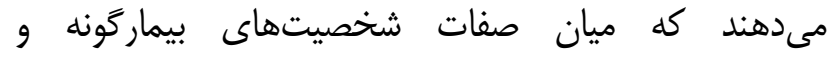
سبكهاى تفكر جرمزا رابطه وجود دارد و اين رابطه (حداقل فئل

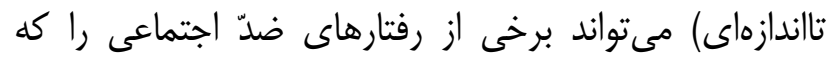
اغلب با صفات شخصيتهاى بيمارگونه (نظير يرخاشگرى) همراه هستند، تبيين نمايد (TV)

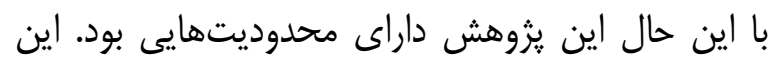
يثوهش فقط شناختارهاى جرمزاى دانشجويان را بررسى كرد و بررسىهاى بيشتر بلمنظور تشخيص اينكه لآيا دانشجويان رهان

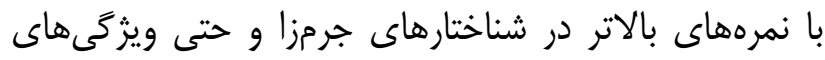

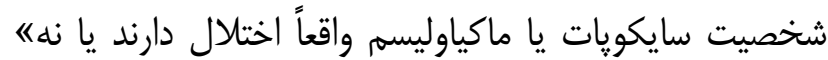

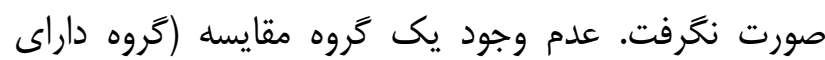

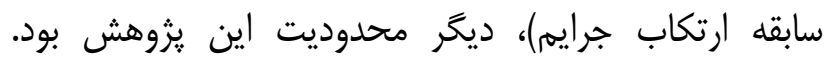

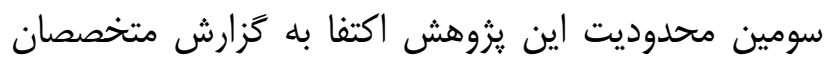

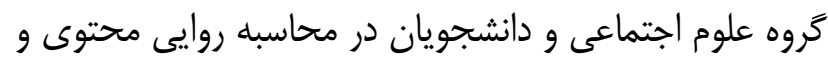

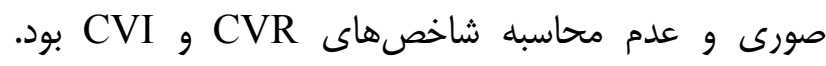

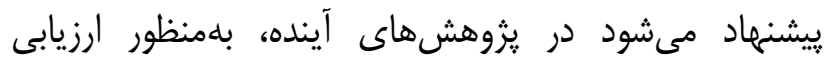

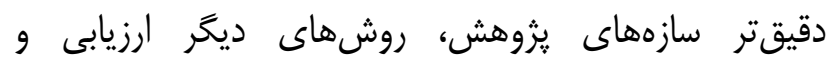

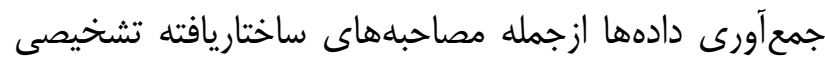

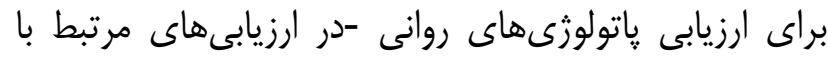

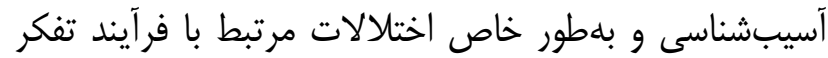

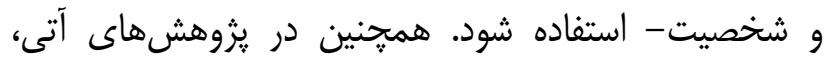
روش گروه-ملاك مورد استفاده قرار گيرد. اين روش كمى مى كند تا باسخهاى گروه عادى و بيمار مقايسه شوند و هر يك از سؤالاتى كه افراد گَروه ملاكى را از افراد تَروه تَواه

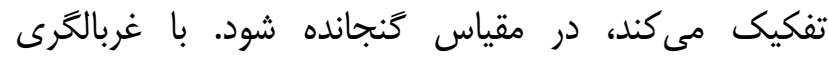

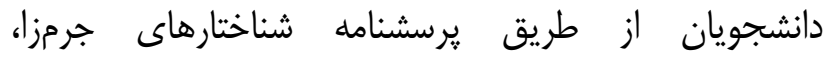

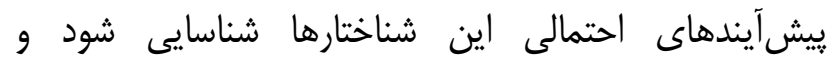

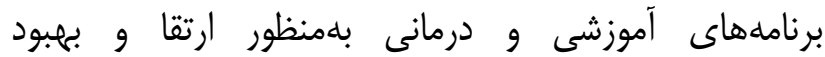
توانمندىهاى روانشناختى مثبت و تعديل ابعاد روانشناختى دمانى

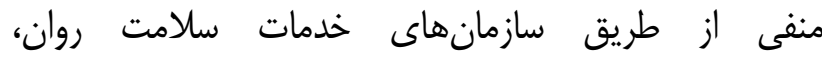

برخى از جرمها در باورها و انتظارات كه در ذهن شخص جاى دارند، وجود دارد. ديدكاه زيربنايى نظريه يادشده اين است كه دها رويدادهاى ذهنى يعنى انتظارات، خاطرات و ... شخص

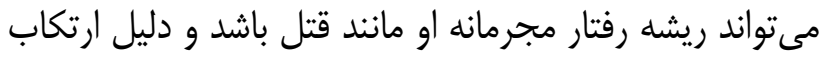
جرم را فراهم سازد (كه).

همسو با رابطه مثبت بين شناختارهاى جرمزا با

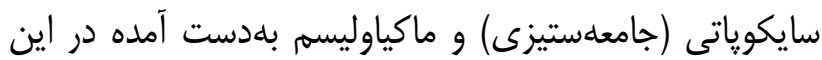
يزوهش، يزوهشى نشان داد كه صفات شخصيتهاى

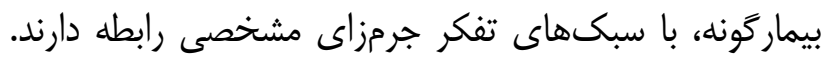

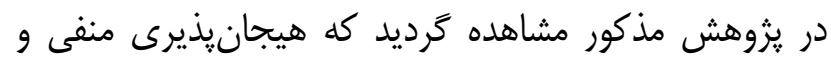

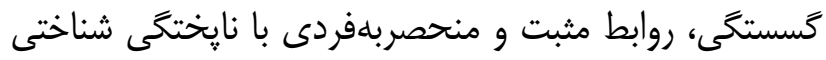

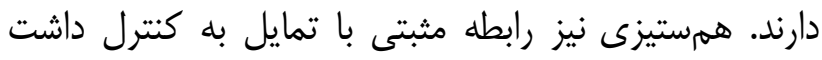

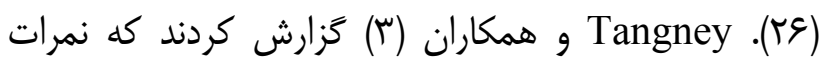

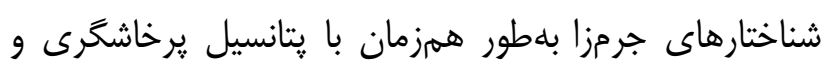

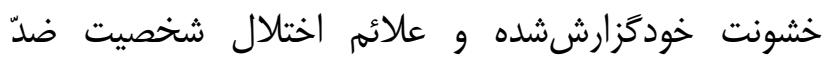

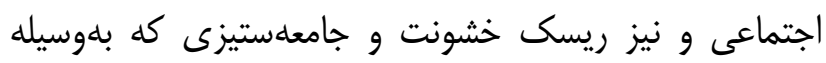
روانشناسان بالينى سنجيده شدهاند، رابطه دارد. علاوه بر ائنس واين،

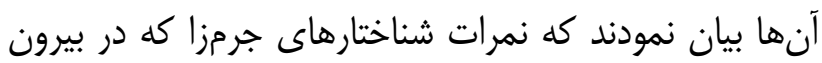

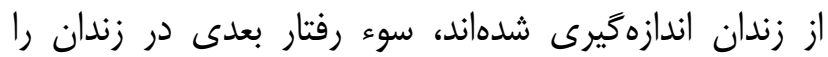
ييشبينى مى كند. همجنين همسو با رابطه منفى بين شناختارهاى جرمزا و درستكارى و همدلى بلدستآمده در اين يزوهش، يافتهانها

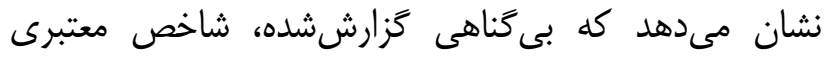
براى دورى از رفتارهاى بزهكارانه بود كه با ييشبينهاى

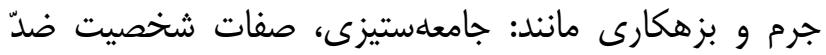
اجتماعى، سوء مصرف مواد و الكل، شناختهاى جرمزا و ويزگى هاى شخصيت مرزى "همبستخى منفى" و با عوامل

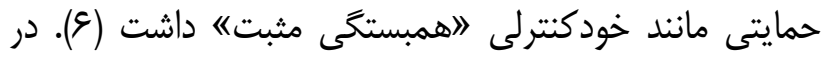
تبيين اين نتايج محققان معتقدند كه شخصيت، عامل مهمى است كه مىتواند در تبيين جرم و رفتار جنايى كمى كند. آنها

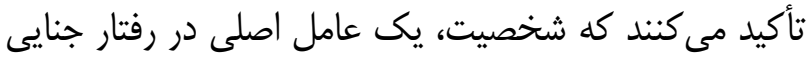
و تنها روش منظه موجود براى بررسى رفتار جنايى است؛ 


$$
\begin{aligned}
& \text { تقدير و تشكر } \\
& \text { نويسندكان مقاله، مراتب تقدير و تشكر خود را از معاونت }
\end{aligned}
$$

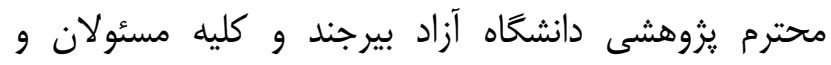

$$
\begin{aligned}
& \text { جمعبندى نتايج اين يزوهش حاكى از روايى و اعتبار }
\end{aligned}
$$

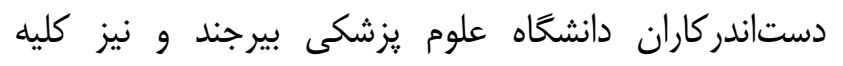

$$
\begin{aligned}
& \text { يرسشنامه شناختارهاى جرمزا در جمعيت دانشجويان دانشعاه ئناه } \\
& \text { شركت كنندكان در اين مطالعه، اعلام مى دارند. }
\end{aligned}
$$

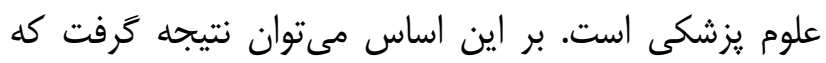

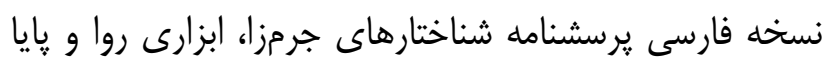

$$
\begin{aligned}
& \text { تضاد منافع } \\
& \text { نويسندَان مقاله اعلام مىدارند كه هيجَّونه تضاد منافعى در }
\end{aligned}
$$

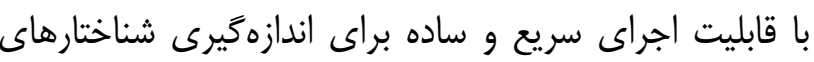

$$
\begin{aligned}
& \text { يثروش حاضر وجود ندارد. }
\end{aligned}
$$

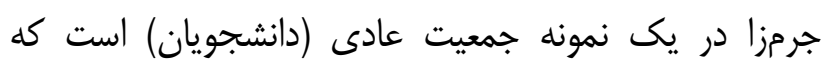

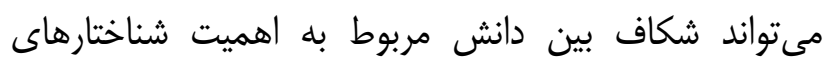

$$
\begin{aligned}
& \text { جرمزا و فقدان كاربردىيذيرى آن را تكميل كند. } \\
& \text { منابع: }
\end{aligned}
$$

1- Gonzalez R, Mandracchia JT, Nicholson B, Dahlen E. Exploring parenting as a predictor of criminogenic thinking in college students. Int J Offender Ther Comp Criminol. 2014; 58(9): 1081-100.

2- Kinard J, Johnson J. Criminogenic risk assessments: What are they and what do they mean for your client? Voice For The Defense Online. 2014 October. Available at: http://www.voiceforthedefenseonline.com/print/2012. Accessed 2018/01/21.

3- Tangney JP, Stuewig J, Furukawa E, Kopelovich S, Meyer PJ, Cosby B. Reliability, validity, and predictive utility of the 25-item Criminogenic Cognitions Scale (CCS). Crim Justice Behav. 2012; 39(10): 1340-60.

4- Schaefer L. Environmental Corrections: Making Offender Supervision Work [dissertation]. Ohio: The University of Cincinnati; 2013.

5- Tangney JP, Mashek D, Stuewig J. Working at the social-clinical-community-criminology interface: The GMU Inmate Study. Soc Clin Psychol. 2007; 26(1): 1-21.

6- Gavel DW. More than mere synonyms: Examining the differences between criminogenic thinking and criminogenic attitudes [dissertation]. Hattiesburg: University of Southern Mississippi; 2017.

7- Youman K. Wrongful incarceration? Race differences in reported innocence among jail inmates [dissertation]. Fairfax, VA: George Mason University; 2014.

8- Moore KE, Milam KC, Folk JB, Tangney JP. Self-stigma among Criminal Offenders: Risk and Protective Factors. Stigma Health. 2018; 3(3): 241-52.

9- Walters GD, McCoy K. Taxometric analysis of the psychological inventory of criminal thinking styles in incarcerated offenders and college students. Crim Justice Behav. 2007; 34(6): 781-93.

10- Reckdenwald A, Ford JA, Murray BN. Alcohol use in emerging adulthood: Can Moffitt's developmental theory help us understand binge drinking among college students? J Child Adolesc Subst Abuse. 2016; 25(6): 497-503.

11- Hooman HA. Analysis of multivariate data in behavioral research. $1^{\text {st }}$ ed. Tehran: Peyke Farhang; 2010. [Persian]

12- Ghomrani M, Samadi M, Taghinejad M, Shamsi A. The study of the validity and reliability of the dark personality scale in students. Journal of psychological models and methods. 2015; 6(20): 73-86. [Persian]

13- Lennick D, Kiel F. Moral Intelligence, Enhancing Business Performance and Leadership Success. $1^{\text {st }}$ ed. New Jersey: Pearson Prentice Hall; 2005. 
14- Rafati SH, rejeh N, Ahmadi-Vash TM, Davati A. A Study of Ethical Intelligence of Medical Students. Medical Ethics J. 2014; 8(27): 71-91. [Persian]

15- Tangney JP, Meyer P, Furukawa, E, Cosby B. The Criminogenic Cognitions Scale. George Mason University; Fairfax, VA; 2002.

16- Veselka L, Giammarco EA, Vernon PH. The dark triad and the seven deadly sins. Pers Individ Dif. 2014 ; 67: 75-80.

17- Ahi Q. Investigating factorial structure, validity and reliability of the seven deadly sins questionnaire among students [Research project]. Birjand; Islamic Azad University, Birjand Branch; 2018. [Persian]

18- Sherretts N, Willmott D. Construct validity and dimensionality of the measure of criminal social identity using data drawn from American, Pakistani, and Polish inmates. J Crim Psychol. 2016; 6(3): 134-43.

19- Disabato DJ, Folk JB, Wilson J, Barboza SH, Daylor J, Tangney J. Psychometric validation of a simplified form of the PICTS for low-reading level populations. J Psychopathol Behav Assess. 2016; 38(3): 456-64.

20- Martíneza VC, Andrés-Pueyob A. The Spanish version of the criminal sentiment scale modified (css-m): factor structure, reliability, and validity. Eur J Psychol Appl L. 2015; 7(2): 67-72.

21- Boduszek D, Adamson G, Shevlin M, Hyland P. Development and validation of a measure of criminal social identity within a sample of polish recidivist prisoners. Crim Behav Ment Health. 2012; 22(5): 315-24.

22- Kishi K, Takeda F, Nagata Y, Suzuki J, Monma T, Asanuma A. The Japanese criminal thinking inventory: Development, reliability, and initial validation of a new scale for assessing criminal thinking in a Japanese offender population. Int J Offender Ther Comp Criminol. 2015; 59(12): 1308-21.

23- Walters GD. Criminal thinking and recidivism: Meta-analytic evidence on the predictive and incremental validity of the psychological inventory of criminal thinking styles (PICTS). Aggress Violent Behav. 2012; 17(3): 272-8.

24- Walters GD. Substance abuse and criminal thinking: Testing the countervailing, mediation, and specificity hypotheses. Law Hum Behav. 2012; 36(6): 506-12.

25- Ghomashi S, Jahangiri E. Cognitive Prevention. Legal Research Quartterly. 2017; 20(3): 299-323. [Persian]

26- Zeigler-Hill V, Mandracchia JT, Dahlenc ER, Shango R, Vrabel Jk. Pathological personality traits and criminogenic thinking styles. Pers Individ Dif. 2017; 110: 41-8.

27- Levine SZ, Jackson CJ. Eysenck theory of crime revisited: Factors or primary scales? Legal and Criminological Psychology. 2004; 9(1): 135-52. 